ORIGINAL ARTICLE

\title{
Obtaining monokaryotic and dikaryotic mycelial cultures of two Amazonian strains of Geastrum (Geastraceae, Basidiomycota)
}

\author{
Marcos Diones Ferreira SANTANA ${ }^{1 *}(\mathbb{0}$, Ruby VARGAS-ISLA², Janaina da Costa NOGUEIRA², \\ Thiago ACCIOLY ${ }^{4}$, Bianca Denise Barbosa da SILVA ${ }^{4}$, Sheyla Regina Marques COUCEIRO ${ }^{1}$, \\ Iuri Goulart BASEIA ${ }^{4}$, Noemia Kazue ISHIKAWA²

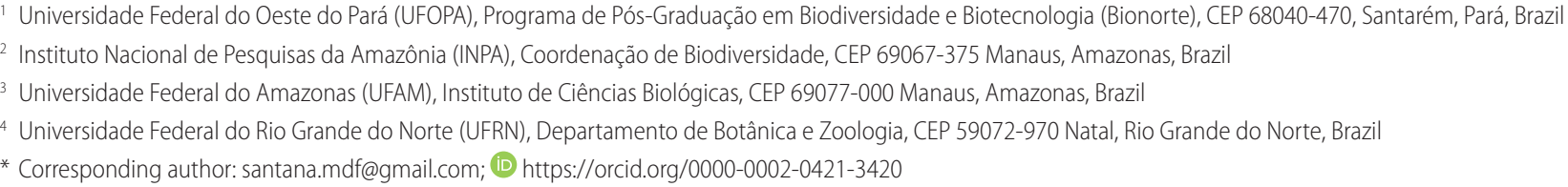

\section{ABSTRACT}

The high diversity of the genus Geastrum and the difficulty of obtaining mycelial cultures impairs the study of the ecophysiology and the exploration of the biotechnological potential of the taxon. In this study, different culture media were tested to obtain mycelial cultures for G. lloydianum and G. subiculosum collected in the Brazilian Amazon. Data on spore germination, and isolation of monokaryotic cultures and in vitro sexual reproduction are presented, as well as a brief morphological description of the cultures obtained. For both species, Potato Dextrose Agar (PDA) was the most promising of the tested culture media. The highest growth in agar culture ever recorded for this genus is reported $(4.9 \mathrm{~mm}$ per week for G. lloydianum and 7.5 $\mathrm{mm}$ for $G$. subiculosum). In the PDA culture medium, spores germinated after 35-40 days of incubation and the isolation of monokaryotic cultures of the two species, as well as in vitro sexual crosses, were successfully performed.

KEYWORDS: earthstars; gasteroid fungus; Geastrum lloydianum; Geastrum subiculosum; mycelial growth

\section{Obtenção de culturas miceliais monocariótica e dicariótica de duas linhagens amazônicas de Geastrum (Geastraceae, Basidiomycota)}

\section{RESUMO}

A alta diversidade do gênero Geastrum e a dificuldade de obtenção de culturas miceliais prejudicam o estudo ecofisiológico e a exploração do potencial biotecnológico do táxon. Nesse estudo, foram testados diferentes meios de cultivo, visando a obtenção de culturas miceliais para G. lloydianum e G. subiculosum coletadas na Amazônia brasileira. A germinação dos esporos, o isolamento das culturas monocarióticas e o cruzamento sexual in vitro são apresentados, além de uma breve descriçáo morfológica das culturas obtidas. O meio de cultura Batata Dextrose Ágar (BDA) foi o mais promissor dentre os meios de cultura testados no cultivo das duas espécies. Reportamos o maior crescimento em cultura de ágar já registrado para esse gênero $(4,9 \mathrm{~mm}$ por semana para $G$. lloydianum e 7,5 mm por semana para G. subiculosum). Nesse meio de cultivo, os esporos germinaram após 35-40 dias de incubação e o isolamento de culturas monocarióticas das duas espécies, assim com os cruzamentos sexuais in vitro, foram realizados com sucesso.

PALAVRAS-CHAVE: estrela-da-terra; crescimento micelial; fungo gasteroide; Geastrum lloydianum; Geastrum subiculosum

\section{INTRODUCTION}

Geastrum Pers. is one of the genera of Basidiomycetes popularly known as earth stars, due to the aspect of the exoperium, that forms rays on dehiscence, conferring a stellariform appearance to mature basidioma (Hemmes and Desjardin 2011; Jeppson et al. 2013). The genus is polyphyletic (Wilson et al. 2011), with approximately 120 species (Zamora et al. 2014), making it the most diversified in the family Geastraceae Corda (Hosaka et al. 2006). Collectively, members of the genus have the ability to colonize a wide variety of environments (Zamora et al. 2013), including sandy soils, and those rich in organic material, as well as acting as a decomposer of wood (Cortez et al. 2011) and having ectomicorrizal associations (Karun and Sridhar 2014). 
Despite the many studies on Geastrum and the contining discovery of new species (Hemmes and Desjardin 2011; Leite et al. 2011; Trierveiler-Pereira et al. 2011; Silva et al. 2011, 2013; Zamora et al. 2013, 2014, 2015; Cabral et al. 2014; Crous et al. 2015; Caffot et al. 2016), the monograph by Sunhede (1989) is, by far, the most complete study on this genus, as it not only considers the morphological aspects of the basidiomas, but also the isolation and the characteristics of the mycelial cultures of diverse European species.

Sunhede (1989) reported the slow in vitro growth of Geastrum cultures, describing a range of 0.5 to $3.7 \mathrm{~mm}$ per week for some species. Stoytchev et al. (2001), studying $G$. pouzarii V.J. Staněk, recorded growth of 3 to $4 \mathrm{~mm}$ in six weeks. Zamora et al. (2014) in a study of G. argentinum Speg., observed up to $4 \mathrm{~mm}$ of growth per week. All these authors considered, it is necessary to improve mycelial growth in this group, mainly due to its potential for antimicrobial, anti-inflammatory, astringent and anti-hemorrhagic activity (Guerra-Dore et al. 2007) in the biotechnological production of bio-active compounds (Liu and Zhang 2004) and in bioremediation (Chittaragi et al. 2013; Sevindik et al. 2017; Kuhar et al. 2016; Santana et al. 2016).

In this study, we tested different mycelial growth media for the Amazon strains of G. lloydianum and G. subiculosum, report spore germination and the succesful rearing of monokaryotic and dikaryotic cultures, in vitro sexual reproduction for both species, and describe the characteristics of the different cultures obtained.

\section{MATERIAL AND METHODS}

\section{Basidioma collection}

Mature basidiomas of G. lloydianum and G. subiculosum were collected by hand at Campus III of Instituto Nacional de Pesquisas da Amazônia (INPA), in the city of Manaus, Amazonas state, Brazil (35'33.0”S, 5959135.0”W).

Basidioma preservation followed the methodology proposed by Lodge et al. (2004). The material was identified following the descriptions of Sunhede (1989), Calonge et al. (2005), Cabral et al. (2014) and Sousa et al. (2014). Part of the collected material was used for evidence and was deposited in the INPA Herbarium (G. lloydianum INPA-Fungos 259923 and G. subiculosum INPA-Fungos 259933).

\section{Obtaining dikaryotic mycelia}

Dikaryotic mycelia of G. lloydianum and G. subiculosum were individually isolated from sections removed from the pseudoparenchymatous layer of a fresh basidial exoperidium and fragments of approximately $1 \times 1 \mathrm{~mm}$ were inoculated onto a $90 \mathrm{~mm}$ diameter Petri dish containing $15 \mathrm{~mL}$ of medium (PDA, Difco ), and then incubated at $25^{\circ} \mathrm{C}$, in the absence of light in a Biological Oxygen Demand (BOD) chamber. After one week, $2 \times 2 \mathrm{~mm}$ agar blocks containing mycelium were harvested and placed on new plates of the same volume and content to give pure cultures.

\section{Evaluation of the mycelial culture medium}

Mycelial growth of G. lloydianum and G. subiculosum was tested in three solid culture media: Potato Agar Dextrose (PDA, Difco ${ }^{\circ}$ ), Malt Extract Peptone Agar (MEPA) [3\% Malt Extract (Becton Dickinson); 0.3\% soy peptone (Acumedia); $1.5 \%$ agar (Becton Dickinson)], and Sabouraud Dextrose Agar (SDA) Becton Dickinson ${ }^{\circ}$. Culture media were autoclaved at $121^{\circ} \mathrm{C}$ for 15 minutes and $15 \mathrm{~mL}$ poured into $90 \mathrm{~mm}$ diameter Petri dishes. A $2 \times 2 \mathrm{~mm}$ fragment from each culture was transferred to the center of a Petri dish and maintained at $25^{\circ} \mathrm{C}$ in the absence of light in the BOD chamber.

The experiment was conducted with a completely randomized design, using five replicates per treatment for each species. On experimental day 42, diameter of colonies and mycelial mass dry weight were measured, following Vargas-Isla and Ishikawa (2008). Mean colony masses and diameters were submitted to analysis of variance (two-way ANOVA) followed by a Tukey test, if significant, with level of significance set at $\mathrm{p}$ $<0.05$. Statistical analyzes were performed with the ASSISTAT program ( 7.7 beta).

\section{Obtaining a monokaryotic mycelium}

Basidiospores of G. lloydianum and G. subiculosum were obtained from suspensions of spores in sterile distilled water, plus $20 \mu \mathrm{L}$ of Tween 80 (Sigma-Aldrich ${ }^{\circ}$ ) stirred lightly on a Vortex ${ }^{\circ}$ agitator. A $50-\mu \mathrm{L}$ aliquot was then spread onto a Petri-dish surface, to test which culture provided the best dikaryotic growth medium for each species, and maintained at $25^{\circ} \mathrm{C}$, in the absence of light in a BOD chamber.

Germinated basidiospores were selected under an optical microscope and transferred to new Petri dishes of volume and content equal to those described above, then maintained under the same conditions and analyzed for growth and absence of connections over a five week period. For each species, the ten monokaryotic cultures showing the highest mycelial growth rates were selected, multiplied with transfer to new Petri dishes and used for crossing tests.

\section{Mycelial crossing}

Crosses were determined by pairing the ten monokaryotic cultures of each species. Fragments measuring $2 \times 2 \mathrm{~mm}$ of the various monokaryotic cultures were inoculated in pairs, seperated by distances of $2 \mathrm{~mm}$ from each other in Petri dishes with $15 \mathrm{~mL}$ of the culture medium that provided the best growth rates in the dikaryotic cultures. These were maintained at five pairs per plate with three replicates and kept at $25^{\circ} \mathrm{C}$ in a BOD chamber in the absence of light and analyzed over a five-week period for the formation of clamp connections. 
After confirming clamp connection formation in cultures of both species, the three cultures with the highest growth for each species were selected and the original crossing-derived dikaryotic mycelium grown-on in new Petri dishes to multiply the stock. After growth, five $2 \times 2 \mathrm{~mm}$ fragments were inoculated into $125 \mathrm{~mL}$ capacity Erlenmeyer flasks, with 50 $\mathrm{mL}$ of the liquid of the culture medium (agar absent) which suported the best dikaryotic culture growth and, in triplicate, maintained in a BOD at $25^{\circ} \mathrm{C}$ in the dark.

After five weeks growth, mycelia were separated from the medium by vacuum-pump filtration, washed three times in sterile distilled water and subjected to DNA extraction following Raeder and Broda (1985).

Amplification of the rDNA internal transcriber-spacer region (ITS) was performed with previously described primers and protocols (Gardes and Bruns 1993). PCR product purification was undertaken with ExoSAP-IT (Affymetrix Inc.), and sequencing was performed with the BigDye ${ }^{\mathrm{\tau}}$ Terminator Cycle Sequencing Ready Reaction Kit GFX (Amersham Pharmacia ${ }^{\circledast}$ ), using the same primers.

Sequences of $G$. hariotii Lloyd, $G$. pectinatum Pers., $G$. triplex Jungh. and G. parvistriatum J.C. Zamora \& Calonge were added in order to test the effectiveness of crosses for species separation. Myriostoma coliforme (Dicks.) Corda was used as an outgroup. Sequences were first aligned with Clustal X 2.1 (Larkin et al. 2007), and then BioEdit (Hall 1999). An ITS-based distance matrix was calculated using the Kimura-2 parameter replacement model with MEGA (Tamura et al. 2013) to assess between species divergence.

Maximum parsimony (MP) phylogenetic analyses with ITS concatenation were performed. For this, PAUP (Swofford 1998) was used, and the trees assembled using a heuristic search for branch exchange using the TBR algorithm. The initial tree was obtained by stepwise addition of 100 repeated random sequencess and 1000 bootstrap repititions. The resulting tree was edited with FigTree (http://tree.bio.Ed.ac. uk/software/figtree/).

\section{RESULTS}

\section{Taxonomy}

Geastrum lloydianum Rick, Brotéria 5: 26 (1906). Figure $1 \mathrm{a}-\mathrm{b}$.

EGeaster lloydianum Rick (1906) [MB\#528074]

EGeastrum saccatum var. lloydianum (Rick) Rick (1961) [MB\#349502]

Basidioma curved expanded, from 14 to $27 \mathrm{~mm}$ in height, including the peristomium, 14 to $27 \mathrm{~mm}$ in diameter, nonhygroscopic, fibrous papyraceous, cotonous, persistent fleshy mycelial layer, detaching itself in irregular brown sections. Endoprosthesis dark grayish brown to dark brown, globose deprescent, with apophysis present, sessile and short stipulate,
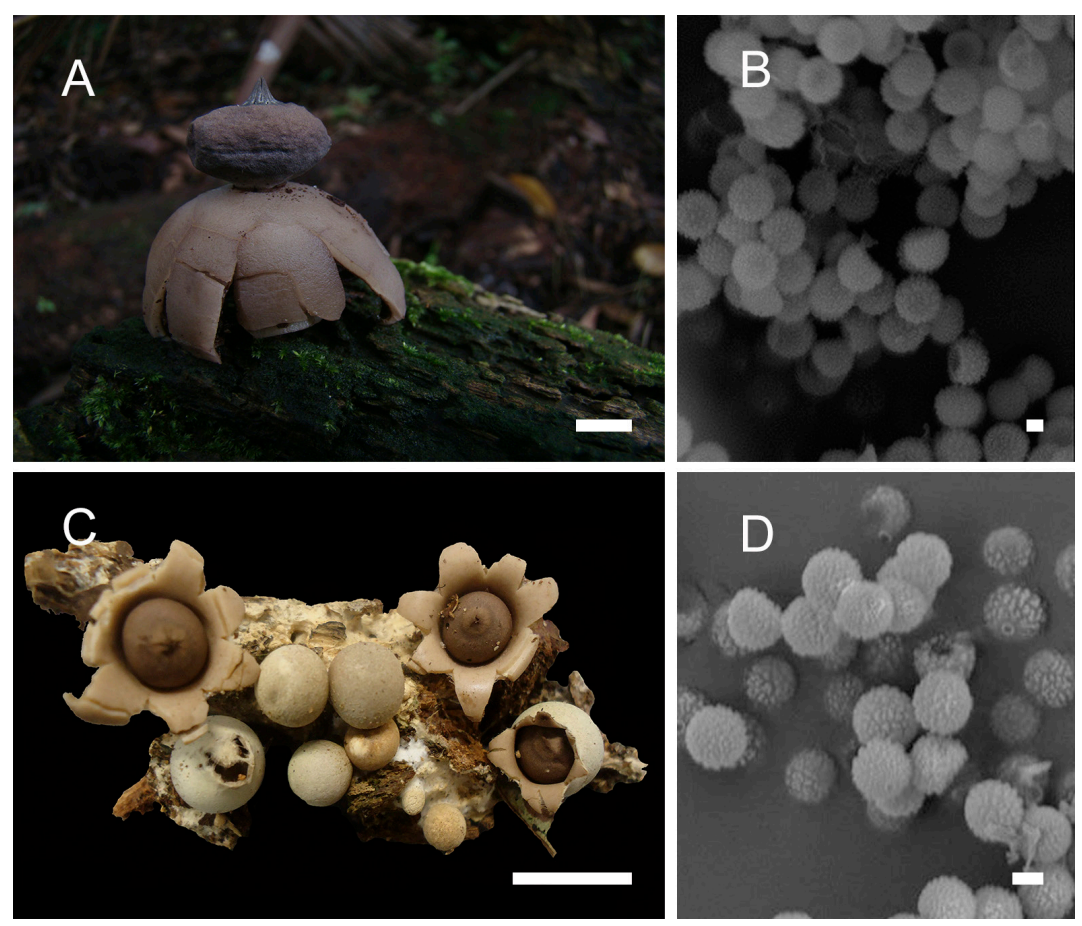

Figure 1. Geastrum lloydianum: A) Immature and expanded basidioma; B) Basidiospores. Geastrum subiculosum:C) Immature and expanded basidioma; D) Basidiospores. Scale bar: $A ; C=1 \mathrm{~cm} ; B ; D=3 \mu \mathrm{m}$. This figure is in color in the electronic version. 
peristomium conical grooved, not delimited and concolorate with endoperidium. Basidiospores globose to subglobose, measuring 3.6 to $5.4 \mu \mathrm{m}$ in diameter, slightly warty, apicule vermilion in presence of $\mathrm{KOH}$.

Material examined: Brazil. Amazonas, Manaus. INPA Campus III, 18 II 2014. Santana, MDF. INPA 259923.

Geastrum subiculosum Cooke \& Massee, Grevillea 15: 97 (1887). Figure 1c-d.

EGeaster subiculosum Cooke \& Massee (1887) [MB\#528132]

$=$ Geaster subiculosum Cooke $\&$ Massee (1887) [MB\#528132]

Immature basidioma subglobous to obovoid, with surface smooth to slightly wrinkled on the subicule, white yellowish to yellowish gray fading to beige. Basidioma expanded with persistent fleshy mycelial layer of yellowish brown to light yellow, with revolte rays cream. Endoperidium dark grayish brown, peristome mamiform, fibrillous, non-delimited, concolor with endoperidium saculiform expansion. Basidiospores small, globose to subglobous, measuring 2.4 to $3.3 \mu \mathrm{m}$ in diameter, slightly warty, hyaline.

Material examined: Brazil. Amazonas, Manaus. INPA Campus III, 22 III 2014. Santana, MDF. INPA 259933.

\section{Evaluation of culture medium in dikaryotic growth}

Despite slow growth, cultures of the two species developed in all tested media (Figure 2). PDA and MEPA produced the best colony diameter values for $G$. lloydianum, with grow rates of some 4.5 and $4.9 \mathrm{~mm}$ per week, respectively. For G. subiculosum, PDA was the best medium, with growth of around $7.5 \mathrm{~mm}$ per week. For G. lloydianum, no significant statistical difference was observed in colony biomass between the culture media. However, for G. subiculosum, PDA and DAS produced the best results (Table 1).

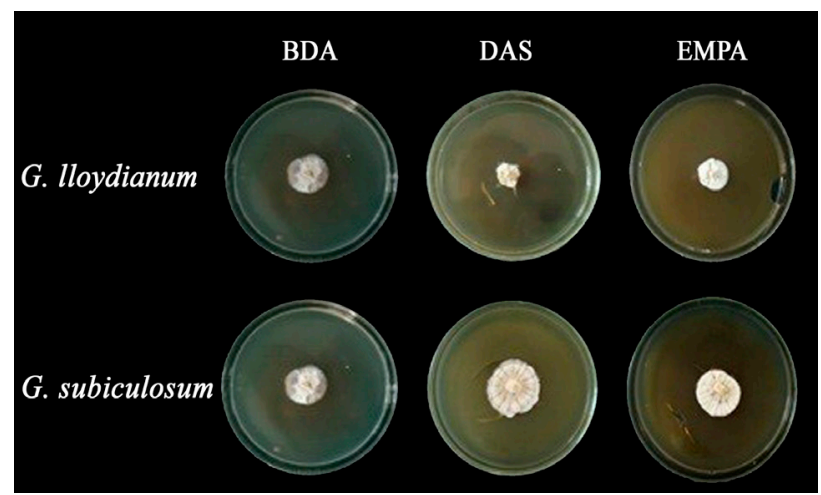

Figure 2. Mycelial cultures of Geastrum Iloydianum and G. subiculosum after 40 days of incubation in different culture media at $25^{\circ} \mathrm{C}$, in the dark. PDA = Potato Dextrose Agar; DAS = Dextrose Agar Sabouraud; MEPA = Malt Extract Peptone Agar. This figure is in color in the electronic version.
Table 1. Evaluation of growth in different culture media by diameter (mm) and biomass (mg) for Geastrum Iloydianum and G. subiculosum over 42 days of incubation at $25^{\circ} \mathrm{C}$ in the dark.

\begin{tabular}{|c|c|c|c|c|c|c|}
\hline \multirow{2}{*}{ Species } & \multicolumn{3}{|c|}{ Mycelial diameter (mm) } & \multicolumn{3}{|c|}{ Colony biomass (mg) } \\
\hline & PDA & DAS & MEPA & PDA & DAS & MEPA \\
\hline Geastrum Iloydianum & $22.3 \mathrm{bA}$ & $11.7 \mathrm{bB}$ & $24.7 \mathrm{aA}$ & $0.07 \mathrm{bA}$ & $0.05 \mathrm{bA}$ & $0.04 \mathrm{aA}$ \\
\hline G. subiculosum & $37.7 \mathrm{aA}$ & $30.7 a B$ & $26.3 \mathrm{aC}$ & $0.25 \mathrm{aA}$ & $0.11 \mathrm{aB}$ & $0.07 a C$ \\
\hline CV (\%) & & 10.27 & & & 20.02 & \\
\hline
\end{tabular}

$\mathrm{BDA}=$ Potato Dextrose Agar; DAS = Dextrose Agar Sabouraud; MEPA = Malt Extract Peptone Agar; VC = Coefficient of Variation. Letters with different sufixes indicate significantly different values among groups (ANOVA, $p<0.05$ ). Small letters refer to comparison between isolates and capital letters, to comparison among treatments.

During the first week of cultivation, G. lloydianum and G. subiculosusm hyphae showed little or no clamp branching of more distant connections. At 42 days, the cultures showed uneven margins, larger hyphae, numerous clamp connections, and the presence of chlamydospores in terminal and interim positions on the hyphae.

\section{Obtaining monokaryotic mycelia}

The germination period of basidiospores of G. lloydianum and G. subiculosum was similar, ranging from 35 to 40 days after incubation. Under these conditions, it was possible to isolate 84 monokaryotic mycelia of G. lloydianum and 96 of G. subiculosum.

Cultures grew, on average, $1.2 \mathrm{~mm}$ per week, but differed in mycelial morphology. Monokaryotic cultures of G. lloydianum on PDA were thicker, with a denser mycelium and a slightly irregular border, while G. subiculosum hyphae were thinner, less dense, with a thin appearence and irregular growth.

The slow development of the two species made it difficult to analyze in vitro pairings. However, the presence of multiple clamp connctions in the resulting mycelium indicated dikaryotic mycelium establishment for all pairs (Figure 3), thus indicating sexual crossing (Taylor et al. 2000; Taylor et al. 2006). The dikaryotic mycelia resulting from in vitro crossings were grouped with the dikaryotic mycelia isolated from the respective basidiomas (Figure 4), showing that the method can likely be employed with other species of the group.

\section{DISCUSSION}

The slow in vitro growth rates of some Geastrum species was first reported by Sunhede (1989), who noted a growth rate variation of 0.5 to $3.7 \mathrm{~mm}$ per week. Stoytchev et al. (2001) reported growth of 3 to $4 \mathrm{~mm}$ after six weeks for $G$. pouzarii V.J. Staněk, and Zamora et al. (2014) observed growth of $4 \mathrm{~mm}$ per week for $G$. argentinum Speg. All these species were grown in a malt extract medium. In this same culture medium, G. lloydianum and G. subiculosum showed higher growth speeds of about 4.6 and $5.2 \mathrm{~mm}$ per week, respectively. 

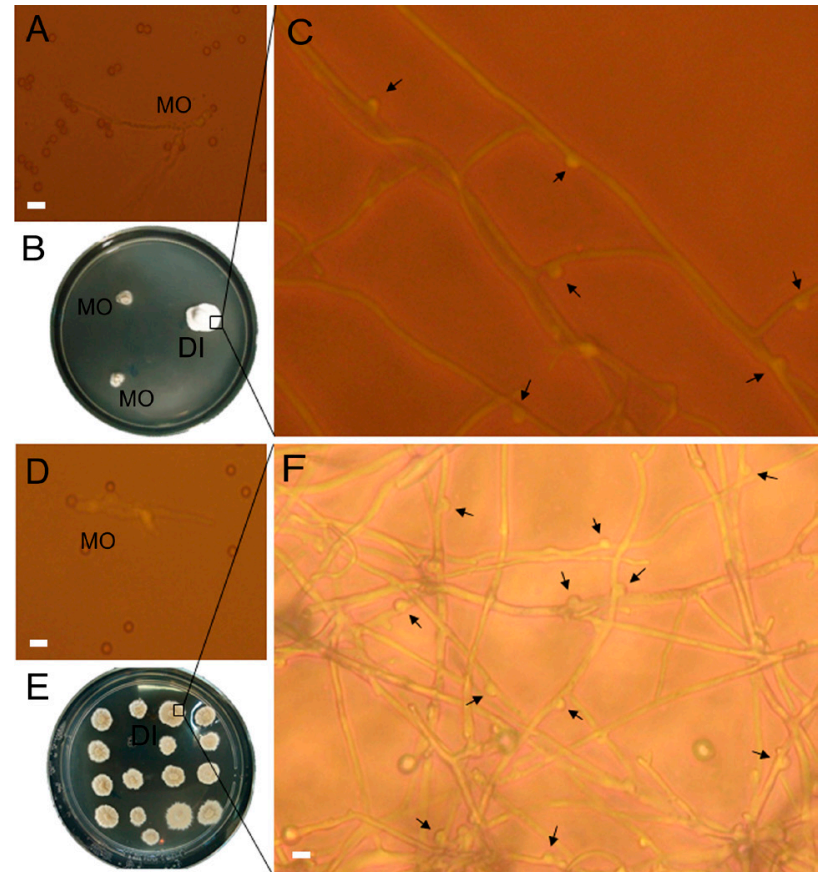

Figure 3. In vitro crossover for two species of Geastrum. A-C) G. subiculosum; D-F) G. Iloydianum, where A) and D) is the monokaryotic mycelium 35 days after incubation; B) is the monokaryotic and dikaryotic mycelium resulting from crossover; E) is the dikaryotic mycelium resulting from crossover; C) and F) show connection clamps indicating success at crossover. $\mathrm{MO}=$ monokaryotic mycelium; $\mathrm{DI}=$ dikaryotic mycelium. This figure is in color in the electronic version.
Both our species showed best results with PDA. This has also been observed for other Geastrum species (G. schweinitzii (Berk. \& M.A. Curtis) Zeller, G. triplex and G. echinulatum B.D.B. Silva \& Baseia (M.D.F. Santana, unpublished data). Although the values are still low, means for mycelial growth in PDA were the most promising recorded so far for the genus.

In vitro germination of sexual spores is the key first step in monokaryotic culture isolation, and can even be used to determine the fungal reproduction system (Anderson $e t$ al. 1980; Carvalho et al. 1997; Capelari and Fungaro 2003), a field of research still little explored for gasteroid fungi. However, the basidiospores of only a few species of Geastrum have germinated under laboratory conditions, the main examples to date being the few cases described by Sunhede (1989) and the report by Stoytchev et al. (2001) for G. pouzarii.

Even if germination rates are low (less than $1 \%$ in this study, for both species) these are the first records of basidiospore germination for both G. subiculosum and $G$. lloydianum. Basidiospore germination for gasteroid fungi, such as Pisolithus Alb. \& Schwein, for example, ranges from 0.001 to $0.38 \%$ (Bulmer 1964; Silvério 2013). This may be the possible cause of the lack of success with previous reported attempts, such as by Kuhar and Papinutti (2009) for $G$. episcopale Kuhar \& Papin, synonym for $G$. violaceum Rick.

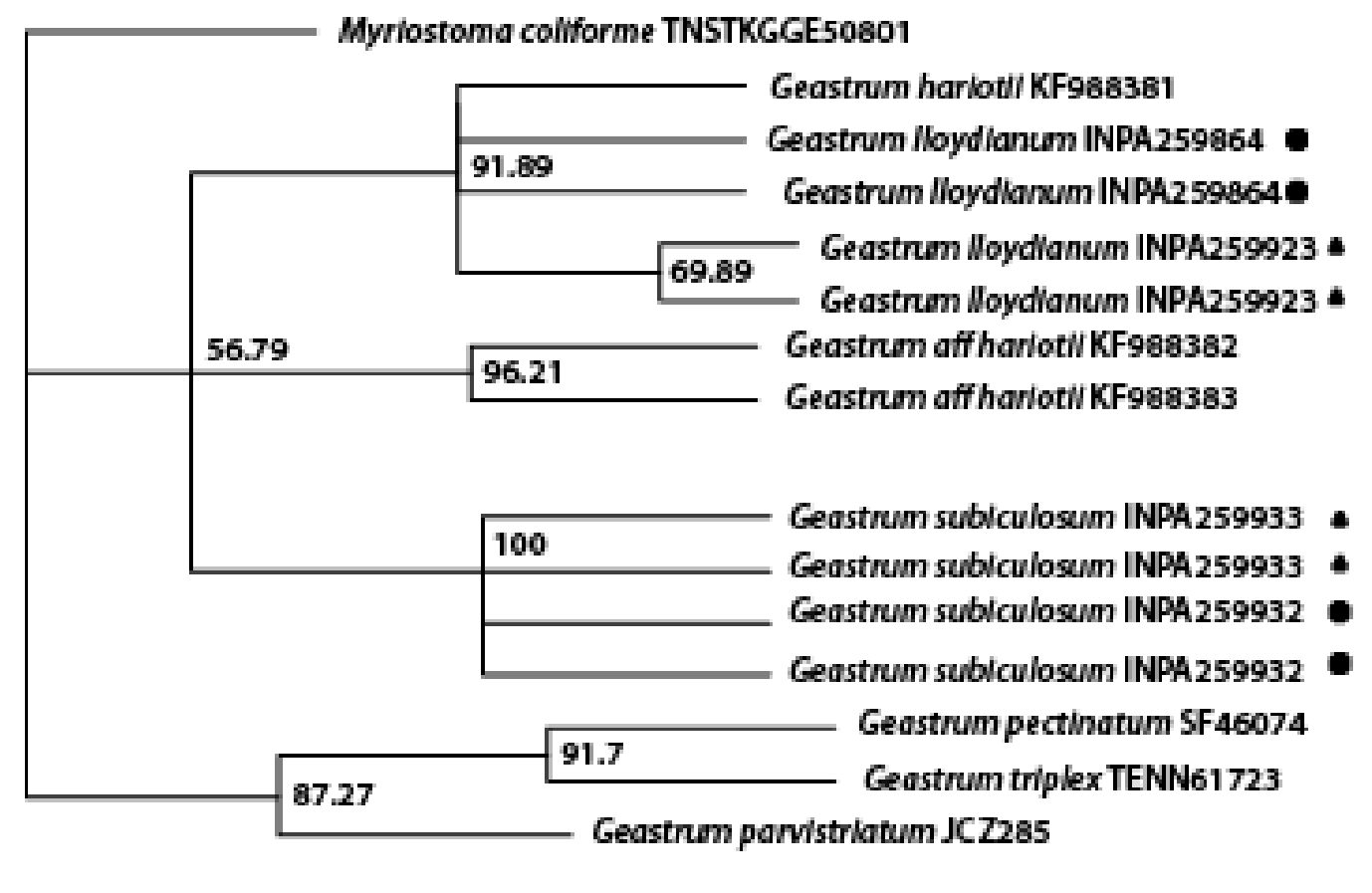

40.0

Figure 4. Molecular similarity between basidioma-derived dikaryotic mycelia (square) and dikaryotic mycelia derived from in vitro crossing (triangle) for Amazonian strains of Geastrum Iloydianum and G. subiculosum. The tree was constructed based on the rDNA ITS region sequences (ITS1, 5.8S and ITS2). 
Low germination rates under laboratory conditions were historically reported in the literature for gasteroid fungi (Bulmer 1964; Fries 1978, 1987; Carvalho et al. 1997; Silvério 2013). For Rhizopogon roseolus (Corda) Th. Fr., the first germination may take two to three weeks (Kawai $e t$ al. 2008) and for Pisolithus arbizus (Scop.) Rauschert., eight weeks after incubation (Carvalho et al. 1997).

\section{CONCLUSIONS}

PDA culture medium was the most promising for mycelial growth of Amazonian strains of Geastrum lloydianum and $G$. subiculosum. This culture medium was also effective for the germination of basidiospores and for obtaining monokaryotic cultures. It is necessary to improve the production of Geastrum mycelial cultures, as well as to apply the methodology used in here to other species, in oredr to broaden the evaluation of its applicability for ecophysiological and biotechnological studies of Geastrum.

\section{ACKNOWLEDGMENTS}

To Coordenação de Aperfeiçoamento de Pessoal de Nível Superior (CAPES) and Programa Nacional de Apoio e Desenvolvimento da Botânica (PNADB) for financial assistance.

\section{REFERENCES}

Anderson, J.B.; Korhonen, K; Ullrich, R.C. 1980. Relationships between European and North American Biological Species of Armillaria mellea. Experimental Mycology, 4: 87-95.

Bulmer, G.S. 1964. The in vitro production of abortive fructifications of Lycoperdon pusillum Pers. Proceedings of the Oklahoma Academy of Science, 44: 192-195.

Cabral, T.S.; Silva, B.D.B.; Marinho, P.; Baseia, I.G. 2014. Geastrum rusticum (Geastraceae, Basidiomycota), a new earthstar fungus in the Brazilian Atlantic rainforest - a molecular analysis. Nova Hedwigia, 98: 265-272.

Caffot, M.L.H.; Amarilla, L.D. Crespo, E.M.; Domínguez, L.S. 2016. Geastrum minutisporum sp. nov. from Polylepis australis woodlands in central Argentina. Mycoscience, 57: 157-163.

Calonge, F.D.; Mata, M.; Carranza, J. 2005. Contribución al catálogo de los Gasteromycetes (Basidiomycotina, Fungi) de Costa Rica. Anales del Jardin Botánico de Madrid, 62: 23-45.

Capelari, M.; Fungaro, M.H.P. 2003. Determination of biological species and analysis of genetic variability by RAPD of isolates of Pleurotus subgenus Coremiopleurotus. Mycological Research, 107: 1050-1054.

Carvalho, D.; Rosado, S.C.S.; Souza, A.M.; Oliveira, A.F. 1997. Produção de culturas monocarióticas e compatibilidade sexual intra e interpopulacional para o fungo ectomicorrízico Pisolithus tinctorius. Cerne, 3: 143-160.

Chittaragi, A.; Naika, R.; Banakar, S.; Vijay, K. 2013. Phytochemical and antifungal study of different solvent extracts of Scleroderma bermudense Corker. (Sclerodermataceae). American Journal of Pharm Tech Research, 3: 427-438.
Cortez, V.G.; Baseia, I.G.; Silveira, R.M.B. 2011. Gasteroid mycobiota of Rio Grande do Sul, Brazil: Lysuraceae (Basidiomycota). Acta Scientiarum. Biological Sciences, 33: 87-92.

Crous, P.W.; Wingfield, M.J.; Le Roux, J.J.; Richardson, D.M.; Strasberg, D.; Shivas, R.G. et al. 2015. Fungal planet description sheets: 371-399. Persoonia, 35: 264-327.

Fries, N. 1978. Basidiospore germination in some mycorrhiza forming hymenomycetes. Transactions of the British Mycological Society, 70: 319-324.

Gardes, M.; Bruns, T.D. 1993. ITS primers with enhanced specificity for basidiomycetes - application to the identification of mycorrhizae and rusts. Molecular Ecology, 2: 113-118.

Guerra-Dore, C.M.P.; Azevedo, T.C.G.; Souza, M.C.R.; Rego, L.A.; Dantas, J.C.M. Silva, F.R.F.; Rocha, H.A.O.; Baseia, I.G.; Leite, E.L. 2007. Antiinflammatory, antioxidant and cytotoxic actions of $\beta$-glucan-rich extract from Geastrum saccatum mushroom. International Immunopharmacology, 7: 1160-1169.

Hall, T.A. 1999. BioEdit: a user-friendly biological sequence alignment editor and analysis program for Windows 95/98/NT. Nucleic Acids Symposium Series, 41: 95-98.

Hemmes, D.E.; Desjardin, D.E. 2011. Earthstars (Geastrum, Myriostoma) of the Hawaiian Islands including two new species, Geastrum litchiforme and Geastrum reticulatum. Pacific Science, 65: 477-496.

Hosaka, K.; Bates, S.T.; Beever, R.E.; Castellano, M.A.; Colgan-III, W.; Domínguez, L.S.; et al. 2006. Molecular phylogenetics of the gomphoid-phalloid fungi with an establishment of the new subclasses Phallomycetidae and two new orders. Mycologia, 98: 949-959.

Jeppson, M.; Nilsson, H.R.; Larsson, E. 2013. European earthstars in Geastraceae (Geastrales, Phallomycetidae): A systematic approach using morphology and molecular sequence data. Systematics and Biodiversity, 4: 437-465.

Karun, N.C.; Sridhar, K.R. 2014. Geasters in the Western Ghats and west coast of India. Acta Mycologica, 49: 207-219.

Kawai, M.; Yamahara, M.; Ohta, A. 2008. Bipolar incompatibility system of an ectomycorrhizal basidiomycete, Rhizopogon rubescens. Mycorrhiza, 18: 205-210.

Kuhar, F.; Castiglia, V.C.; Zamora, J.C. 2016. Detection of manganese peroxidase and other exoenzymes in four isolates of Geastrum (Geastrales) in pure culture. Revista Argentina de Microbiología, 48: 274-278.

Kuhar, F.; Papinutti, L. 2009. Geastrum episcopale: a new noticeable species with red-violet exoperidium. Mycologia, 101: 535-538.

Larkin, M.A.; Blackshields, G.; Brown, N.P.; Chenna, R.; McGettigan, P.A.; McWilliam, H.; et al. 2007. Clustal W and Clustal X version 2.0. Bioinformatics, 23: 2947-2948.

Leite, A.G.; Assis, H.K.; Silva, B.D.B.; Sotão, H.M.P.; Baseia, I.G. 2011. Geastrum species from the Amazon Forest, Brazil. Mycotaxon, 118: 383-392.

Liu, Y.J.; Zhang, K.Q. 2004. Antimicrobial activities of selected Cyathus species. Mycopathologia, 2: 185-189.

Lodge, D.J.; Ammirati, J.; O’Dell, T.E.; Mueller, G.M. 2004. Collecting and describing macrofungi: Inventory and Monitoring Methods. In: Mueller, G.M.; Bills, G.; Foster, M.S. 
(Eds.). Biodiversity of Fungi: Inventory and Monitoring Methods. Elsevier Academic Press, San Diego, C.A., p.128-158.

Raeder, U.; Broda, P. 1985. Rapid preparation of DNA from filamentous fungi. Letters in Applied Microbiology, 1: 17-20.

Santana, M.D.F.; Rodrigues, L.D.S.I.; Amaral, T.S.; Pinheiro, Y.G. 2016. Fenoloxidase e biodegradaçáo do corante têxtil Azul Brilhante de Remazol R (RBBR) para três espécies de macrofungos coletadas na Amazônia. SaBios-Revista de Saúde e Biologia, 11: 53-60.

Sevindik, M.; Akgul, H.; Akata, I.; Selamoglu, Z. 2017. Geastrum pectinatum as an alternative antioxidant source with some biochemical analysis. Medical Mycology, 3: 1-4.

Silva, B.D.B.da; Cabral, T.S.; Marinho, P.; Ishikawa, N.K.; Baseia, I.G. 2013. Two new species of Geastrum (Geastraceae, Basidiomycota) found in Brazil. Nova Hedwigia, 96: 445-456.

Silva, B.D.B.; Sousa, J.O.; Baseia, I.G. 2011. Discovery of Geastrum xerophilum from the Neotropics. Mycotaxon, 118: 355-359.

Silvério, M.A.M. 2013. Permeabilizaçâo e ultraestrutura da parede celular de basidiósporos de Pisolithus microcarpus. Master's dissertation, Universidade Federal de Viçosa, Brazil. 53p.

Sousa, J.O.; Silva, B.D.B.; Alfredo, D.S.; Baseia, I.G. 2014. New records of Geastraceae (Basidiomycota: Phallomycetidae) from Atlantic rainforest remnants and relicts of Northeastern Brazil. Darwiniana, new series, 2: 207-221.

Stoytchev, I.; Homolka, L.; Nerud, F. 2001. Geastrum pouzarii Staněk in agar culture. Antonie van Leeuwenhoek, 79: 363-364.

Sunhede, S. 1989. Geastraceae (Basidiomycotina). Morphology, ecology and systematics with special emphasis on the North European species. Synopsis Fungorum, 1: 1-534.

Swofford, D.L. 1998. PAUP*. Phylogenetic Analysis Using Parsimony ( ${ }^{*}$ and Other Methods). Version 4.0 b. Sinauer Associates, Sunderland, Massachusetts, 142p.

Tamura, K.; Stecher, G.; Peterson, D.; Filipski, A.; Kumar, S. 2013. MEGA6: molecular evolutionary genetics analysis version 6.0. Molecular Biology and Evolution, 12: 2725-2729.
Taylor, J.W.; Jacobson, D.J.; Kroken, S.; Kasuya, T.; Geiser, D.M.; Hibbett, D.S.; Fisher, M.C. 2000. Phylogenetic species recognition and species concepts in fungi. Fungal Genetics and Biology, 31: 21-32.

Taylor, J.W.; Turner, E.; Townsend, J.P.; Dettman, J.R.; Jacobson, D. 2006. Eukaryotic microbes, species recognition and the geographic limits of species: examples from the kingdom Fungi. Philosophical Transactions of the Royal Society B, 361: 1947-196.

Trierveiler-Pereira, L.; Gomes-Silva, A.C.; Baseia, I.G. 2011. Observations on gasteroid Agaricomycetes from the Brazilian Amazon rainforest. Mycotaxon, 118: 273-282.

Vargas-Isla, R.; Capelari, M.; Menolli Jr, N.; Nagasawa, E.; Tokimoto, K.; Ishikawa, N.K. 2015. Relationship between Panus lecomtei and. P. strigellus inferred from their morphological, molecular and biological characteristics. Mycoscience, 56: 561-571.

Wilson, A.W.; Binder, M.; Hibbet, D.S. 2011. Effects of gasteroid fruiting body morphology on diversification rates in three independent clades of fungi estimated using binary state speciation and extinction analysis. Evolution, 5: 1305-1322

Zamora, J.C.; Calonge, F.D.; Hosaka, K.; Martin, M.P. 2014. Systematics of the genus Geastrum (Fungi: Basidiomycota) revisited. Taxon, 63: 477-497.

Zamora, J.C.; Calonge, F.D.; Martín, M.P. 2015. Integrative taxonomy reveals an unexpected diversity in Geastrum section Geastrum (Geastrales, Basidiomycota). Persoonia: Molecular Phylogeny and Evolution of Fungi, 34: 130-165.

Zamora, J.C.; Calonge, F.D.; Martín, M.P. 2013. New sources of taxonomic information for earthstars (Geastrum, Geastraceae, Basidiomycota): phenoloxidases and rhizomorph crystals. Phytotaxa, 132: 1-20.

RECEIVED: 08/05/2019

ACCEPTED: 03/10/2019

ASSOCIATE EDITOR: Claudia Keller 